\title{
Upaya Masyarakat Daerah Pariwisata Candidasa Kabupaten Karangasem dalam Mempertahankan Keberadaan Bahasa Bali
}

\author{
I Putu Pande Suargita, I Ketut Sudarsana \\ Institut Hindu Dharma Negeri Denpasar \\ iketutsudarsana@ihdn.ac.id
}

\begin{abstract}
In the use of Balinese language in the community of Candidasa tourism area, there are some obstacles encountered by the community, namely the lack of interest to learn the language of Bali, the influence of association, and because of the social class in the community. To preserve the existence of Balinese language, the people of Candidasa tourism area made several efforts, namely introducing Balinese language early, using Balinese language in family environment, and instilling a sense of love of Balinese culture.
\end{abstract}

Keywords: Balinese language, tourism area

\section{Pendahuluan}

Kehidupan manusia sehari-hari dalam beraktivitas selalu berkaitan dengan bahasa, oleh sebab itu bahasa memiliki peranan yang sangat penting sebagai pengantar dalam menyampaikan pesan tertentu kepada seseorang untuk dapat diterima dan dimengerti. Untuk dapat dimengerti suatu maksud berupa pesan disampaikan dengan perantara bahasa yang jelas sebagai alat pengantar, (Kertiasih, 2012 :72). Demikian pula yang terjadi di daerah pariwisata Candidasa. Dalam kehidupan sehari-hari masyarakat menggunakan bahasa sebagai alat komunikasi, baik bahasa Bali, bahasa Indonesia, maupun bahasa lainnya. Wilayah tempat tinggal yang ramai dikunjungi oleh wisatawan menyebabkan adanya banyak bahasa yang dugunakan oleh masyarakat daerah pariwisata Candidasa. Penggunaan bahasa Bali terus diupayakan untuk digunakan dalam kehidupan sosial masyarakat agar tidak punah dan tergerus oleh budaya lain.

Bahasa Bali merupakan bahasa ibu yang dimiliki oleh masyarakat Bali yang patut dilestarikan, dijaga serta dikembangkan. Meskipun lingkungan tempat tinggal mengharuskan warga masyarakatnya menggunakan bahasa selain bahasa Bali, masyarakat Bali harus tetap mempertahankan bahasa dan budaya sendiri. Pengaruh-pengaruh yang ada di lingkungan masyarakat harus diminimalisir agar bahasa Bali tetap menjadi pilihan utama masyarakat penutur (Suartana, 2017).

Berdasarkan kutipan di atas, dapat disimpulkan bahwa lingkungan tempat tinggal yang memberikan pengaruh kurang baik terhadap penggunaan bahasa Bali harus di minamilisirkan. Untuk menjaga, melestarikan dan mengembangkan bahasa Bali merupakan tugas seluruh masyarakat Bali baik dari kalangan pemerintah, tenaga pendidik dan masyarakat umum serta generasi muda. Oleh sebab itu, diperlukan adanya upaya serta usaha-usaha dalam rangka melestarikan dan mengambangkan budaya Bali yang didalamnya termasuk bahasa Bali.

Bahasa Bali adalah salah satu bahasa daerah di negara Indonesia yang dipelihara dengan baik oleh penuturnya, yakni masyarakat etnis Bali. bahasa Bali sebagai bahasa ibu atau sebagai bahasa pertama bagi sebagian besar masyarakat Bali, dipakai secara luas sebagai alat komunikasi dalam berbagai aktivitas kehidupan sosial masyarakat Bali, baik dalam situasi resmi maupun tidak resmi (Suarjana, 2008). Menurut Keraf (dalam Parwati 2011 :21), memberikan dua pengertian bahasa. Pengertian pertama menyatakan bahasa sebagai alat komunikasi antara anggota masyarakat berupa simbol bunyi yang dihasilkan oleh alat ucap manusia. Kedua, bahasa adalah system komunikasi yang mempergunakan simbol-simbol vokal (bunyi ujaran) yang bersifat arbitrer.

Setiap individu memiliki bakat dan kemampuan tersendiri yang berbeda satu dengan yang lainnyadalam hal berbahasa. Baik buruknya seseorang dalam berbahasa sangat dipengaruhi oleh banyak hal, baik itu faktor dari dalam diri ataupun faktor dari luar yang nantinya sangat menentukan kemampuan berbahasa seseorang. Faktor dari dalam diri tersebut dapat berupa potensal dan munat untuk mempelajari bahasa itu sendiri yang nantinya akan menjadi motivasi untuk lebih maju. Sedangkan faktor dari luar dapat berupa lingkungan sekitar, seperti keluarga, sekolah dan juga lingkungan pergaulan. Apabila kedua faktor ini saling mendukung maka akan menjadi hal yang baik dalam pembelajaran bahasa. Namun apabila salah satu ataupun keduanya tidak saling mendukung, hal tersebut akan menjadi penghambat bagi seseorang dalam mempelajari suatu bahasa (Sukayasa, 2011 :59). Dalam menjalani hidup, manusia pasti pernah mempunyai kendala. tidak ada hidup tanpa kendala, bahkan untuk seseorang yang sangat pintar pun pernah mengalami kendala-kendala dalam menghadapi hidupnya. Kendala adalah suatu masalah yang 
harus dipecahkan. Kendala adalah bagian dari kehidupan, (Abdul Cholil, dalam Kertiasih 2012 : 36). Demikian halnya dengan masyarakat yang tinggal di daerah pariwisata Candidasa Karangasem. Dalam menggunakan bahasa Bali sebagai bahasa pengantar dalam kehidupan seharihari, tentu akan mengalami kendala-kendala yang akan menjadi tantangan dalam melestarikan bahasa dan budaya Bali pada arus globalisasi di tengah-tengah perkembangan pariwisata Candidasa yang semakin pesat.

Tidak ada sesuatu yang kekal, kecuali perubahan. Hal ini menunjukkan tidak ada sesuatu pun di dunia ini yang luput dari perubahan. Dengan demikian, eksistensi perubahan tidak pernah terlewatkan dari kenyataan hidup manusia, baik sebagai individu maupun sebagai masyarakat. Comte (dalam Triguna, 2008:1), mengatakan bahwa dalam hubungan kebudayaan manusia senantiasa mengalami proses perubahan dengan segala konsekuensi yang menyertainya, baik disebabkan oleh kebutuhan untuk berubah maupun perubahan yang direncanakan.

Pitana (1994:4) mengemukakan perubahan merupakan suatu ciri yang sangat hakiki dalam masyarakat dan kebudayaan. Ini berarti perubahan sosial merupakan gejala umum dalam masyarakat yang dikarenakan adanya komunikasi masyarakat dengan gagasan-gagasan baru, masyarakat menyadari akan keterbelakangannya dan adanya ikatan kesadaran berorganisasi yang relatif lebih baik. Dalam konteks ini, perubahan sosial turut mempengaruhi masa depan hidup masyarakat yang mengalaminya.

Salim (2002:132) mengemukan bahwa perubahan sosial disebabkan oleh pengaruh luar terhadap sendi-sendi kehidupan internal, seperti unsur produktivitas masyarakat tradisional, sikap mental, kemampuan organisasi, ragam etnik, mundurnya sektor ekonomi, serta pengaruh modernisasi. Selain itu, faktor eksternal juga berpengaruh terhadap aspek-aspek struktural masyarakat yang oleh Salim dikatakan sebagai 'mesin penggerak' perubahan sosial, seperti informasi komunikasi yang meliputi pengaruh media massa dengan bentuk industri pers, birokrasi yang meliputi keterkaitan birokrasi sipil dengan birokrasi militer, ideologi yang meliputi agama dan Hak Asasi Manusia (HAM), modal yang meliputi modal finansial dan Sumber Daya Manusia (SDM), teknologi yang meliputi unsur yang cepat berubah dan sangat tergantung kepada pemikiran modal.

Menurut Hegel dan Max (dalam Kayam, 1989), menggambarkan proses perubahan sosial adalah reproduction atau menghasilkan kembali segala sesuatu yang diterima sebagai warisan budaya dari nenek moyang kita sebelumnya. Proses ini berkenaan dengan usaha untuk menjadikan bahasa Bali sebagai suatu kebanggan identitas seperti pada masa lampau, melalui penciptaan ranah-ranah baru untuk penggunaan bahasa Bali, seperti adanya penyelenggaraan lomba berpidato dan menulis cerita berbahasa Bali secara berkesinambungan. Selain itu, perubahan sosial juga digambarkan sebagai proses transformation yakni suatu proses penciptaan hal yang baru yang dihasilkan oleh ilmu pengetahuan dan teknologi seperti kontak person dalam siaran tembangtembang Bali oleh Bali TV.

Garvin dan Mathiot menyatakan bahwa sikap bahasa yang positif terkait dengan kesetiaan bahasa, kebanggaan bahasa, dan kesadaran terhadap norma bahasa. Sedangkan sikap bahasa yang negatif terkait dengan hal-hal sebaliknya, yakni ketidaksetiaan bahasa, ketidakbanggan bahasa, dan ketidaksadaran terhadap norma bahasa, (Jendra, 2008 : 110). Jika dilihat dari realitasnya, sikap bahasa masyarakat daerah pariwisata Candidasa karangasem cenderung positif. Ini dapat dilihat dari pilihan bahasa yang digunakan dalam berkomunikasi sehari-hari di lingkungan masyarakat adalah bahasa Bali. Walaupun dalam penggunaannya masih bercampur dengan bahasa lainnya seperti bahasa Indonesia dan bahasa asing, tetapi hal tersebut terjadi sesuai dengan situasi pada saat berkomunikasi.

Perubahan bahasa adalah perbedaan bentuk, fungsi, dan makna pada sebuah bahasa seiring dengan perubahan waktu, (Jendra, 2011 : 1148). Faktor yang mendorong terjadinya perubahan bahasa di daerah pariwisata Candidasa Karangasem adalah faktor migrasi penduduk, sikap penutur, penemuan dan penyebaran tekhnologi. Berdasarkan penelitian di daerah pariwisata Candidasa Karangasem, terdapat beberapa hal yang menjadi kendala masyarakat dalam menggunakan bahas bali sebagai bahas pengantar.

\section{Pembahasan}

Pariwisata adalah segala sesuatu yang berhubungan dengan prjalanan untuk rekreasi (Tim Penyusun, 2002 : 830). Ditinjau dari segi etimologisnya, kata pariwisata terdiri dari dua suku kata yaitu kata "pari" dan "wisata". Pari berarti banyak, berkali-kali, berputar-putar, lengkap. Wisata berarti perjalanan, bepergian yang dalam hal ini sinonim dengan kata travel dalam bahasa Inggris. Atas dasar tersebut, maka kata pariwisata seharusnya diartikan sebagai perjalana yang dilakukan berkali-kali atau berputar-putar, dari suatu tempat ke tempat lain, yang dalam bahasa inggris disebut dengan kata tour, sedangkan untuk pengertian ajamak, kata kepariwisataan dapat digunakan kata tourisme atau tourism (Yoeti, 1990 : 103). 
Daerah pariwisata adalah suatu tempat atau keadaan alam yang memiliki sumber daya alam yang dibangun dan dikembangkan sehingga mempunyai daya tarik yang diusahakan sebagai tempat yang dikunjungi wisatawan. Karangasem merupakan wilayah paling timur dari Pulau Bali. Banyak terdapat tempat wisata di daerah Karangasem baik berupa tempat wisata alam ataupun tempat wisata yang dibuat oleh manusia yang terkenal sekarang seperti rumah pohon. Objek wisata alam yang sudah banyak dikenal seperti Amed, Tulamben, Candidasa, dll.

Candidasa merupakan suatu wilayah kecil dari sebuah desa yaitu desa Bugbug. Tepatnya berada di wilayah Banjar Samuh Desa Bugbug. Candidasa ramai dikunjungi oleh wisatawan asing maupun lokal, yang merupakan objeknya yakni pemandangan lautnya. Seiring dengan perkembangan jaman, banyak berdiri hotel, villa, bungalow, restaurant, dan sebagainya, yang berkaitan dengan pariwisata di daerah ini. Perkembangan pembangunan tersebut juga membuka peluang kerja bagi masyarakat lokal disana maupun daerah sekitarnya yang berkompeten pada bidang pariwisata. Selain bangunan-bangunan yang berkaitan dengan pariwisata, di Candidasa juga terdapat sebuah Pura yang sering disebut Pura Candidasa. Pura ini disungsung oleh seluruh masyarakat Desa Bugbug. Pada hari raya tertentu seperti Galungan dan Kuningan, banyak masyarakat dari luar Desa Bugbug yang datang dan melaksanakan persembahyangan di Pura Candidasa ini, seperti masyarakat dari desa Nyuh Tebel, Pesedahan, Sengkidu, Ngis, dan sekitarnya. Terdapat sebuah kolam diseberang jalan di depan Pura Candidasa yang nampak indah dengan bunga teratai yang menghiasi kolam. Menambah indah pemandangan di candidasa apabila dilihat dari puncak Pura Candidasa.

Sor-singgih basa Bali merupakan tingkatan-tingkatan berbicara dalam bahasa Bali. Di Bali, bahasa Bali memiliki beberapa tingkatan yang meliputi Basa Bali kasar, Basa Bali andap, Basa Bali madya, Basa Bali Alus dan Basa Bali Mider. Sor singgih basa Bali dipakai oleh masyarakat Bali sebagai alat komunikasi dalam berbagai kehidupan di Bali, seperti hubungan dalam keluarga, masyarakat dan sebagainya (Kertiasih, 2012 :36). Adanya sor singgih basa Bali membuat masyarakat Bali utamanya generasi muda sedikit enggan menggunakan bahasa Bali ketika berbicara dengan orang lain terutama orang yang lebih tua atau seseorang yang memiliki kedudukan tinggi, seperti pejabat dan lain-lain. Hal ini disebabkan karena kurangnya pemahaman tentang penempatan tingkatan-tingkatan bahasa tersebut. Martini menyatakan bahwa adanya sor singgih basa Bali membuatnya bingung dan tidak berani menggunakan bahasa Bali sebagai bahasa pengantar ketika berbicara dengan seseorang yang yang usianya lebih tua, apalagi berbicara dengan seseorang yang memiliki kedudukan lebih tinggi, seperti pejabat, para guru, dan lain sebagainya. Pernyataan Martini tersebut juga sejalan dengan pernyataan Suarta yang memilih menggunakan bahasa Indonesia ketika sudah kebingungan untuk menempatkan sor singgih basa Bali yang baik dan benar sesuai dengan tingkatan bahasa pada saat berbicara dengan seseorang yang dihormati dan disegani di lingkungannya.

Sor singgih basa Bali memang cukup sulit untuk dipelajari. Hal ini disebabkan karena banyaknya kosa kata bahasa Bali yang berbeda arti dan nilai rasanya ketika digunakan oleh seseorang. Misalnya penggunaan kata "makan" yang bahasa Bali alus singgihnya adalah "ngarayunang" dan bahasa Bali alus sornya adalah "nunas". Apabila kata "makan" ditujukan untuk seseorang dari golongan Tri Wangsa atau seseorang dengan kedudukan lebih tinggi maka digunakan kata "ngarayunang". Contoh : "I Ratu sampun ngarayunang?". Kata "ngarayunang" memiliki nilai rasa bahasa yang lebih alus, digunakan untuk meninggikan atau menghormati seseorang karena masuk dalam tataran kruna alus singgih. Sedangkan kata "nunas" digunakan untuk seseorang yang berasal dari wangsa jaba atau kedudukan lebih rendah. Contoh : "Saking semengan titiang durung polih nunas". Kata "nunas" memiliki rasa bahasa yang lebih rendah, dan digunakan untuk merendahkan atau ngasorang dewek, karena masuk dalam tataran kruna alus sor.

Kendala yang dialami oleh masyarakat dalam menggunakan bahasa Bali terkait dengan adanya sor singgih basa Bali tidak hanya dialami oleh masyarakat daerah pariwisata Candidasa saja. Hal ini terjadi hampir diseluruh daerah di Bali, baik di lingkungan pedesaan maupun perkotaan, (Geriya, 2008 : 131). Hal ini harusnya mendapat perhatian dari seluruh kalangan masyarakat, pemerintah, dan juga pemerhati bahasa Bali untuk meningkatkan kembali pengajaranpengajaran bahasa Bali baik melalui pembelajaran formal di sekolah ataupun non formal di lingkungan masyarakat.

Pada dasarnya sikap bahasa generasi muda cenderung positif dan bangga menggunakan bahasa Bali sebagai bahasa pengantar komunikasi sehari-hari. Namun adanya sor singgih basa Bali dirasa menjadi kendala sehingga menyulitkan penggunaan bahasa pada saat berbicara dengan seseorang yang pantas diitinggikan, seperti golongan Tri Wangsa, para pejabat dan lain sebagainya. Hal inilah yang menyebabkan terjadinya kekeliruan bahkan keengganan dan ketakutan generasi muda sebagai generasi penutur untuk mengggunakan bahasa Bali sebagai bahasa komnikatif dalam kesehariannya. Kekeliruan yang terjadi dalam percakapan generasi muda dalam penggunaan sor singgih basa Bali ini dikarenakan minimnya pengetahuan generasi muda tentang 
penggunaan sor singgih bahasa Bali yang dianggap susah. Hal inilah yang menjadi kendala yang harus segera diupayakan cara-cara untuk mengatasinya. Merupakan tugas masyarakat, pemerintah, tenaga pendidik, dan seluruh komponen masyarakat Bali untuk bersama-sama memberikan pengajaran tentang bahasa Bali kepada generasi muda dan masyarakat secara umum sejak usia dini.

Bahasa bali yang merupakan bahasa ibu masyarakat etnis Bali juga menjadi salah satu muatan lokal di sekolah formal tingkat pendidikan SD sampai dengan SMA. Bahasa Bali merupakan suatu bahasa yang unik karena selain ada tingkatan-timgkatan bahasanya, juga memiliki bentuk tulisannya sendiri yang disebut aksara Bali (Miniawati, 2017). Penulisan aksara Bali tentu berbeda dengan penulisan huruf latin. penulisan latin dalam bahasa Bali maupun bahasa Indonesia akan sesuai dengan ejaan yang disempurnakan dalam bahasa tersebut. Berbeda dengan penulisan aksara Bali. Pada saat mennulis dengan aksara Bali, akan ditulis apa yang diucapkan, tidak sesuai dengan tulisan latinnya. Adanya dua bentuk tulisan ini membuat generasi muda utamanya para generasi enggan untuk mempelajari serta mendalami bahas Bali. Hal tersebut sejalan dengan kutipan pustaka berikut :

Malajahin bahasa Bali ketah karasayang meweh antuk para siswane duaning nganggen kalih huruf, inggih punika huruf latin miwah aksara Bali. Sasuratan nganggen aksara Bali punika sering mawinan jejeh para siswane. yadiastun asapunika, duaning aksara Baline pinaka warisan budaya sane kabaos adi luhung tur patut karajegang, para siswane patut mautsaha saha oneng mlajahin aksarane punika, (Suwija, 2013:39).

Belajar bahasa Bali sering dirasa susah oleh siswa karena menggunakan dua huruf, yaitu huruf latin dan aksara Bali. Penulisan menggunakan aksara Bali sering membuat siswa takut. Walaupun demikian, karena aksara Bali merupakan warisan budaya yang adi luhung, patut dilestarikan, para siswa harus berusaha dan giat mempelajari aksara tersebut, (Suwija, $2013: 39$ ).

Dari uraian tersebut diatas, dapat disimpulkan bahwa penggunaan dua huruf dalam bahasa Bali menjadi salah satu hal yang membuat siswa takut dan enggan untuk mempelajari bahasa Bali. Adanya aksara Bali yang dirasa sulit oleh siswa, membuat minat belajar siswa sangat minim. MInimnya minat untuk mampelajari bahasa Bali ini berpengaruh terhadap penggunaan bahas Bali di lingkungan masyarakat. Artinya, karena minat belajar yang minim, masyarakat khususnya generasi muda yang msih duduk di bangku sekolah hanya menggunakan bahasa Bali lumrah dan kepara saja. Terlebih lagi adanya pengaruh lingkungan tempat tinggal yang merupakan daerah pariwisata yang ramai dikunjungi oleh wisatawan baik dalam negeri ataupun luar negeri. Intensitas penggunaan bahasa bali menjadi semakin menurun.

\section{Pengaruh Bahasa Pergaulan}

Manusia terlahir sebagai makhluk sosial dalam menjalankan kehidupannya akan berinteraksi dan bersosialisasi dengan manusia-manusia lainnya, baik yang berada dalam satu wilayah ataupun wilayah yang berbeda. Penggunaan bahasa tentu akan berbeda menyesuaikan dengan situasi dan kondisinya. Perkembangan zaman seperti sekarang sangat mempengaruhi penggunaan bahasa khususnya anak muda yang sudah mulai menggunakan bahasa selain bahasa Bali dalam berinteraksi baik di dalam keluarga maupun lingkungan masyarakat.

Pergaulan masyarakat sangat memberikan pengaruh terhadap kelakuannya, termasuk cara berbicara dan penggunaan bahasanya. Hal tersebut juga terjadi di daerah pariwisata Candidasa Karangasem. Seorang warga masyarakat asli Candidasa yang kuliah di Denpasar dan kesehariannya bergaul dengan orang-orang perkotaan juga mengalami perubahan bahasa.

Generasi muda memiliki pandangan bahwa bahwa menggunakan bahasa Indonesia terkesan lebih modern daripada menggunakan bahasa Bali. Hal ini menyatakan generasi muda beranggapan bahwa bahasa Bali itu ketinggalan zaman dan katrok. Menurut Suartana, generasi muda yang seperti ini memiliki pemahaman yang kurang terhadap budaya-budaya bali, serta kurang mencintai kebudayaan Bali itu sendiri. Hal yang harus dilakukan adalah memberika pemahaman tentang kebudayaan-kebudayaan Bali agar tumbuh rasa bangga terhadap kebudayaan Bali (Suartana, 2017). Pengaruh pergaulan menjadi salah satu kendala yang dihadapi oleh masyarakat daerah pariwisata Candidasa dalam penggunaan bahasa Bali.

\section{Pengaruh Perkembangan Zaman}

Kendala selanjutnya yang dihadapi masyarakat daerah pariwisata Candidasa dalam penggunaan bahasa Bali adalah adanya pengaruh perkembangan zaman. Perkembangan zaman pada era globalisasi atau era modern ini ditandai dengan berkembangnya ilmu pengetahuan dan tekhnologi yang semakin canggih. Perkembangan tekhnologi misalnya, zaman dulu orang-orang rela melakukan perjalanan jauh dengan berjalan kaki dalam menjalani kehidupannya, namun sekarang seiring dengan perkembangan tekhnologi, manusia membuat sepeda motor dan bahkan mobil untuk mendukung dan mempermudah kehidupan masyarakat. Jika zaman dulu manusia menggunakan surat untuk menyampaikan berita atau informasi kepada rekan-rekannya yang 
berada jauh dari jangkauan, maka kini orang-orang sudah memiliki handphone atau telephone genggam untuk mempermudah komunikasi. Begitu pesat perkembangan dan kemajuan tekhnologi zaman sekarang, tentu memberikan dampak yang baik dan kurang baik dalam kehidupan masyarakat. Salah satu dampak lain yang diakibatkan oleh perkembangan zaman adalah mempengaruhi penggunaan bahaasa Bali sebagai bahasa komunikatif dalam kehidupan bermasyarakat bagi masyarakat etnis Bali.

Pulau Bali yang pada umumnya dihuni oleh masyarakat yang kebanyakan sebagai penutur bahasa Bali. Semenjak zaman kemerdekaan, menyebabkan masyarakat Bali telah semakin maju dalam berbagai bidang kehidupan, seperti pendidikan, ekonomi, sosial budaya dan lain-lain. Kemajuan dalam berbagai bidang kehidupan itu telah menyebabkan masyarakat semakin bercampur dengan etnis bangsa asing. Saat ini masyarakat Bali sebagai penutur bahasa Bali telah menjadi masyarakat majemuk. Penutur bahasa Bali semakin banyak menerima pengaruh, baik dari dalam maupun luar daerah. Akibatnya pergeseran pemakaian bahasa Bali telah menjadi masalah yang sangat disoroti pada saat ini, (Sukayasa, $2011: 64$ ).

Perkembangan kemajuan zaman seperti sekarang ini membuat terjadinya perubahan bahasa terutama di kalangan remaja. Terlebih lagi pengaruh internet dan tayangan-tayangan televisi yang semakin marak belakangan ini. Pengaruh perkembangan tekhnologi tersebut dirasa menjadi salah satu faktor yang menyebabkan perubahan bahasa yang dialami oleh masyarakat utamanya kaum anak-anak dan remaja di daerah pariwisata Candidasa ini.

\section{Adanya Kelas Sosial Masyarakat}

Kelas sosial adalah merupakan gejala yang serba hadir dalam setiap kehidupan sosial, artinya dalam kehidupan sosial selalu ada pola-pola penggolongan manusia dalam kelompok dengan berbagai kriteria yang melekat dalam diri masing-masing anggota kelompok tersebut ( Setiadi dan Kolip, 2010 : 424). Biasanya kelas sosial terdiri dari sejumlah orang yang memiliki status sosial baik yang diperoleh berdaasarkan kelahiran, perjuangan untuk meraaih status sosial, dan karena pemberian. Adanya kelas sosial atau status-status sosial di masyarakat juga mempengaruhi penggunaan bahasa yang dirasakan sebagai kendala yang membuat penutur bahasa Bali utamanya generasi muda merasa kesusahan dalam berkomunikasi. Dalam tulisan ini yang dimaksud dengan kelas sosial adalah berupa golongan pengusaha, pejabat, pemandu wisata, dan sebagainya. Kendala yang dihadapi dalam kelas sosial yang dimaksud dalam penelitian ini adalaha penggunaan bahas yang berbeda dan tidak selalu menggunakan bahasa Bali sebagai bahasa komunikatif yang dikhawatirkan juga memberikan dampak yang lebih besar terhadap perkembangan bahasa Bali.

\section{Upaya Masyarakat}

Upaya untuk menjaga keberadaan bahasa Bali harus digalakkan, karena kemungkinan besar pergeseran dan kepunahan bahasa Bali akan terjadi apabila hal tersebut tidak dilaksanakan. Masih terdapat banyak kendala yang ditemui oleh penutur bahasa Bali pada saat menggunakan bahasa Bali sebagai pengantar dalam berkomunikasi. kendala-kendala tersebut yang nantinya akan mendorong kemunduran penggunaan bahasa Bali di lingkungan masrayakat daerah pariwisata Candidasa Karangasem. Masyarakat daerah pariwisata Candidasa bekerja sama dengan perangkat desa serta instansi terkait untuk berupaya menjaga kebertahanan bahasa Bali di daerah pariwisata Candidasa Karangasem. Upaya-upaya yang dilakukan masyarakat dalam rangka menjaga keberadaan bahasa Bali di daerah pariwisata Candidasa adalah sebagai berikut :

Berbahasa sangat erat kaitannya dengan budaya sebuah generasi. adaya berbagai macam dan ragam bahasa menimbulkan masalah, bagaimana penggunaan bahasa di dalam masyarakat (Chaer, 1994 :63). Penguasaan sebuah bahasa oleh seorang anak dimulai dengan pemerolehan bahasa pertama yang sering disebut dengan bahasa Ibu. Bahasa Ibu adalah bahasa yang pertama kalidikuasai oleh seseorang sejak awal hidupnya, (Sukayasa, 2011 :68). Kondisi kebahasaan generasi muda zaman sekarang cukup memperihatinkan, hal tersebut yang mendorong masyarakat daerah pariwisata candidasa mulai mengajarkan atau memperkenalkan bahasa Bali sejak usia dini. Cahyani mengungkapkan bahwa penggunaan bahasa Bali harus diperkenalkan sejak usia dini agar pada saat tumbuh dewasa, mereka sudah terbiasa menggunakan bahasa Bali. pengenalan bahasa Indonesia merupakan bahasa kedua yang diperkenalkan ketika mulai menginjak usia sekolah (Cahyani, 2017). Pendapat tersebut sejalan dengan yang disampaikan oleh Dharma, bahwa sangat penting untuk memperkenalkan bahasa Bali sebagai bahasa Ibu kepada anak sejak berusia dini, agar menjadi kebiasaan untuk menggunakan bahasa Bali dalam kehidupan sehari-hari, (Dharma, 2017).

Kehidupan sosial masyarakat di Bali diwarnai dengan adanya perbedaan golongan masyarakat. Yakni adanya golongan Tri Wangsa dan Wangsa Jaba yang dalam berkomunikasi menggunakan bahasa Bali sesuai dengan sor singgih bahasa Bali. Oleh karena itu, bahasa Bali harus diperkenalkan sejak usia dini, agar ketika sudah dewasa nanti masyarakat Bali sudah fasih menggunakan bahasa Bali sebagai bahasa pengantar dalam segala situasi pada saat berkomunikasi. 
Suweta merupakan salah seorang warga yang merantau ke kota menyatakan bahwa sudah memperkenalkan bahasa Indonesia kepada anak-anknya sejak kecil, dan sampai dewasa terbiasa menggunakan bahasa Indonesia. Hal tersebut dilakukan karena lingkungan sekitarnya yaitu daerah kota yang masyarakatnya kebanyakan menggunakan bahasa Indonesia. Ketika kembali pulang ke daerah asalnya di Candidasa, anak-anaknya mengalami kendala dalam menggunakan bahasa Bali, terlebih ketika mereka berkomunikasi dengan kakek maupun neneknya yang kebiasaan sehariharinya menggunakan bahasa Bali, (Suweta, 2017). Melihat fenomena di atas dapat diambil kesimpulan bahwa pengenalan bahasa Bali sejak kecil perlu dilakukan oleh para orang tua, meskipun tinggal di daerah perkotaan. Supaya ketika bersosialisasii di lingkungan masyarakat tidak terkendala dengan penggunaan bahasa Bali sebagai bahasa komunikasi.

Suartana menyatakan bahwa menggunakan bahasa Bali sebagai bahasa pengantar seharihari merupakan suatu kebanggan tersendiri, karena mampu mempertahankan budaya-budaya yang dimiliki serta menunjukkan sikap cinta terhadap budaya sendiri, (Suartana, 2017). Dari pernyataan tersebut disimpulkan bahwa menggunakan bahasa Bali merupakan wujud dari kecintaan seseorang terhadap budaya yang dimiliki. Agar budaya-budaya bangsa tetap lestari dan tidak tergerus oleh kemajuan zaman dan budaya-budaya asing di zaman glonalisasi seperti sekarang.

Dilihat dari segi pendidikan, penggunaan bahasa Indonesia yang tidak mengenal tingkatan dalam bahasa Bali dikenal dengan istilah kasta, menyebabkan hilangnya etika serta sopan santun saat berkomunikasi dengan orang yang lebih tua serta dari msyarakat berkasta, (Sukayasa, 2011:71). Pengenalan kosa kata bahasa indonesia sejak kecil membuat anak semakin lupa akan pengenalan kosa kata bahasa Bali yang berkonotasi halus dan kasar yang sangat erat kaitannya dengan pelestarian bahasa Bali. Hal ini menyebabkan setiap anak yang berkomunikasi beranggapan bahwa yang diajak berkomunikasi kedudukannya sejajar atau sepadan. dapat dikatakan bahwa pengenalan kosa kata bahasa Bali sejak dini memberikan dampak yang cukup besar terhadap keberadaan dan perkembangan bahasa Bali.

Keluarga merupakan orang seisi rumah seperti : ayah, ibu, adik, kakak, kakek, nenek, sanak saudara dan sebagainya yang menjadi tanggung jawab dan sering berkunjung ke rumah serta mejadi satuan kekerabatan dalam lingkungan masyarakat ( Kamus Besar Bahasa Indonesia, 1991 : 471). Ariana menyatakan bahwa lingkungan keluarga merupakan tempat bersosialisasi paling kecil dan paling dekat dengan seseorang. Oleh sebab itu sangat disarankan untuk menggunakan bahasa Bali sebagai bahasa pengantar dalam berkomunikasi, agar kebiasaaan tersebut diikuti oleh anak-anak hingga dewasa nanti (Ariana, 2017). Hal tersebut sejalan dengan pendapat Dharma yang menyatakan bahwa bahasa Bali merupakan bahasa ibu yang patut dijaga dan dilestarikan. Dimulai dari lingkup kecil yakni diri sendiri dalam lingkungan keluarga, sehingga kebiasaan ini diikuti oleh anggota keluarga lainnya. Menurut Dharma, jika bahasa Bali sudah dibunakan dalam ruang lingkup keluarga, maka akan mempermudah ketika bersosialisasi di lingkungan masyarakat dengan warga lainnya, (Dharma, 2017). Dari pernyataan diatas dapat dinyatakan bahwa satu keluarga yang dengan konsisten menggunakan bahasa Bali akan mampu memberikan pengaruh terhadap warga masyarakat lainnya agar ikut serta menggunakan bahasa Bali sebagai bahasa pengantar dalam berkomunikasi. Suartana menyatakan bahwa masyarakat Bali harus konsisten menggunakan bahasa Bali sebagai bahasa pengantar pesan dalam kehidupan sehari-hari. Termasuk juga generasi muda di luar Bali agar tetap menggunakan bahasa Bali saat berkomunikasi dengan sesama orang Bali walaupun ada banyak bahasa lain yang dirasa lebih bergengsi untuk digunakan, (Suartana, 2017).

Berdasarkan pengamatan di lapangan, pilihan bahasa yang digunakan oleh masyarakat dalam lingkungan keluarga adalah bahasa Bali kapara yang biasa digunakan dalam situasi keakraban. Sering juga terjadi percampuran bahasa Bali dengan bahasa lainnya pada saat pembicaraan-pembicaraan tertentu. seperti kutipan dialog dalam sebuah keluarga yang membicarakan tentang teknologi berikut ini :

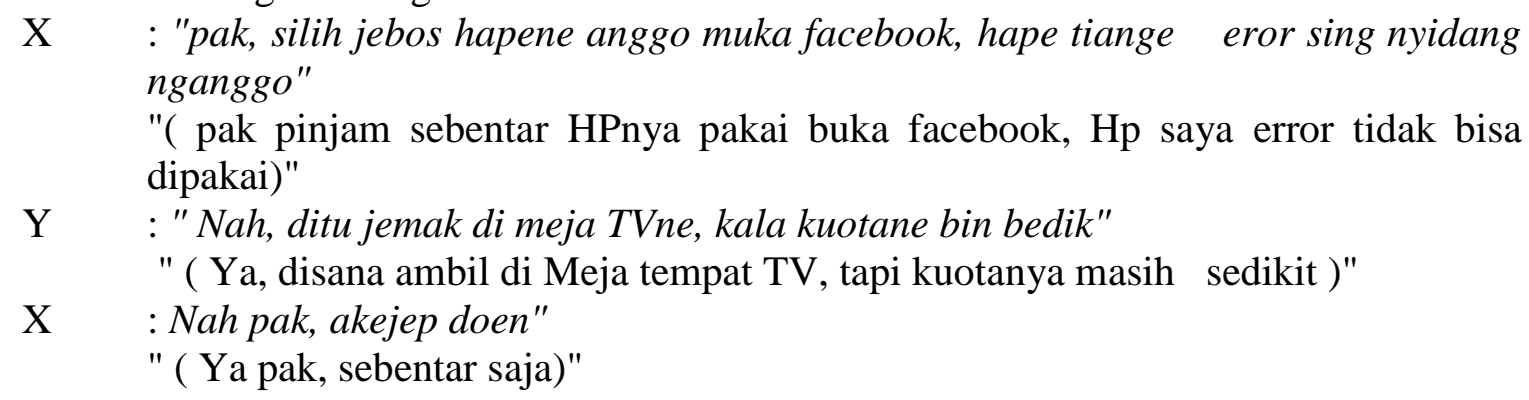

Dialog diatas tersebut terdapat kosa kata yang berasal dari bahasa asing seperti facebook dan lain sebagainya. Tetapi secara umum bahasa yang digunakan adalah bahasa Bali. Digunakannya bahasa asing dalam dialog tersebut karena untuk mengucapkan istilah-istilah tekhnologi yang tidak ada padanan katanya dalam bahasa Bali. Dengan demikian dapat disimpulkan bahawa masyarakat daerah pariwisata Candidasa menggunakan bahasa Bali dalam 
kegiatannya sehari-hari di lingkungan keluarga, terkadang menggunakan bahasa lainnya pada saat pembicaraan-pembicaraan tertentu mengenai tekhnologi, dan lain sebagainya.

Pengertian kebudayaan mencakup benda dan peralatan karya manusia, sedangkan inti kebudaayn itu terdiri atas nilai-nilai budaya yang merupakan hasil abstraksi pengalaman dari pendukungnya, yang selanjutnya menguasai sikap dan tingkah laku manusia, (Geriya, 2008 :15).

Secara akademik, kebudayaan dengan pengertian yang amat luas mencakup seluruh sistem gagasan dan rasa, tindakan, serta karya yang dihasilkan manusia dalam kehidupan bermasyarakat, yang dijadikan miliknya dengan belajar. Dengan pengertian yang sempit, kebudayaanmterbatas pada segala sesuatu yang indah, misalnya candi, tarian, seni rupa, seni suara, (Koentjaraningrat dalam Geriya, 2008 :15). Kebudayaan sebagai perwujudan dari hasil cipta, rasa dan karsa manusia dalam akativitasnya sebagai makhluk hidup yang berbudaya. Perkembangan dan keberdayaan kebudayaan selalu menuntut penajaman cipta, penghalusan rasa, serta pemantapan karsa dalam rangka pengembangan dan peningkatan mutu peradaban dan eksistensi manusia. Dinamika dan tranformasi kebudayaan berlangsung melalui mekanisme kekuatan internal, kekuatan eksternal, kekuatan interpretasi, atau kekuatan konstruktuf, ( Ki Hajar Dewantara dalam Geriya, 2008).

Identitas budaya adalah ciri khusus suatu kebudayaan yang membedakan kebudayaan tersebut dengan kebudayaan-kebudayaan yang lain. Identitas budaya dibentuk oleh unsur-unsur kebudayaan tertentu seperti sistem lambang, sistem nilai, sistem bahasa, kesenian, organisasi sosial, sistem ritual, Kajuan koentjaraningrat terhadap kebudayaan-kebudayaan nusantara mengungkapkan bahwa unsur bahasa dan kesenian merupakan dua unsur kebudayaan yang berfungsi sangat mendasar bagi identitas budaya nusantara, (Geriya, 2008 :18). Berdasarkan uraian tersebut maka dapat disimpulkan bahwa bahasa memegang peranan penting terhadap perkembangan budaya nusantara. Hal tersebut sejalan dengan pendapat Waskita Dharma yang menyatakan bahwa untuk menyebar luaskan kebudayaan yang dimiliki, diperlukan bahasa sebagai media pengantarnya. Oleh karena itu hal perlu dilakukan adalah menjaga bahasa yang dimiliki untuk dilestarikan agar mampu menyebarluaskan atau mengembangkan kebudayaan-kebudayaan lainya, (Dharma, 2017).

Suartana menyatakan bahwa menanamkan rasa bangga dan cinta terhadap budaya Bali khususnya dirasa sangat penting dilakukan. terlebih lagi pada perkembangan zaman seperti sekarang ini. Pengaruh perkembangan zaman memberikan dampak yang cukup besar terhadap perkembangan budaya dan segala unsurnya. Oleh sebab itu, masyarakat Bali harus dibentengi dengan rasa cinta dan bangga terhadap budaya Bali. Terlebih lagi lingkungan tempat tinggal yang merupakan daerah pariwisata yang tentu banyak dikunjungi oleh wisataaawan baik dalam maupun luar negeri yang membawa abudayanya msing-masing, (Suartana, 2017). Hal tersebut sejalan dengan pendapat Martini yang menyatakan bahwa pengaruh budaya luar akan dengan cepat dan mudah mempengaruhi masyarakat Bali khususnya anak muda yang saat ini senang mengikuti trend-trend dari luar daerah maupun luar negeri, (Martini, 2017). Generai muda khususnya yang ada di daerah pariwisata Candidasa pada saat ini senang mengikuti trend yang mereka lihat di televisi, seperti trend cara berpakaian atau menggunakan pakaian-pakaian modis seperti yang sering dilihat di televisi, trend penggunaan bahasa yang juga sering mereka dengarkan pada tayangan-tayangan sinetron atau film-film di televisi. Penting untuk mengingatkan kembali kepada mereka atau para generasi muda agar tetap mencintai dan bangga dengan budaya-budaya Bali yang merupakan warisan leluhur. Berbagai kegiatan dilakukan oleh masyarakat daerah pariwisata Candidasa untuk meningkatkan rasa cinta dan bangga terhadap kebudayaan Bali serta merangsang generasi muda untuk mempelajari kebudayaan Bali. Miniawati menyatakan bahwa untuk meningkatkan minat dan semangat generasi muda dalam melestarikan dan mengembangkan budaya Bali maka di selenggarakan beberapa lomba yang berkaitan dengan seni dan budaya Bali,seperti lomba Pidarta bahasa Bali, lomba masatua Bali, lomba nyurat aksara Bali dan lain sebagainya, (Miniawati, 2017).

Masyarakat Bali memiliki organisasi atau kelompok sosial yang lebuh kecil sifatnya dan bergerak dalam lapangan hidup yang khusus, dikenal dengan istilah sekaa. Sekaa merupakan kesatuan dari beberapa Banjar yang menghimpun diri atas dasar kepentingan yang sama (Bagus dan Astika dalam Geriya, 2008 :133). Berdasarkan aktivitas atau jenis kegiatannya, sekaa dapat diklasifikasikan antara lain sekaa yang bergerak dalam aspek kehidupan ekonomi, seperti sekaa mula, sekaa majukut, manyi, jukung, dan lain-lain. Sekaa yang bergerak dalam aspek sosial seperti sekaa pamaksan, patus, sambang, tempek, truna-truni dan lain-lain. Sekaa yang bergerak dalam aspek adat dan Agama seperti sekaa kidung, makekawin, dan lain-lain. Sekaa yang bergerak dalm bidang kesenian seperti sekaa barong, arja, sanghyang, drama, joged, dan lain-lain. Sekaa yang bergerak dalam aspek penyaluran hoby seperti sekaa layangan, semal, tuak, tajen, dan lain-lain, (Astika, dalam Geriya $2008: 133$ ).

Masyarakat daerah pariwisata Candidasa Desa Bugbug ini membentuk beberapa sekaa yang bergerak dalam aspek adat dan Agama yaitu sekaa kidung dan makekawin, serta sekaa yang 
bergerak dalam aspek kesenian yaitu sekaa tari dan sekaa gong. Adanya sekaa di masing-masing Banjar di Desa Bugbug ini merupakan tanggung jawab dari masing-masing kelihan Banjar yang dalam kegiatannya dibantu dan bekerja sama dengan sekaa truna-truni di masing-masing Banjar tersebut.

\section{Penutup}

Penggunaan bahasa Bali di daerah pariwisata Candidasa masih menemukan kendalakendala sehingga menghambat perkembangan bahasa Bali. Kendala-kendala tersebut adalah minimnya minat untuk belajar bahasa bali. Hal ini disebabkan karena adanya aksara Bali yang dirasa susah oleh kalangan pelajar dan generasi muda. sikap ini cenderung kurang positif karena beberapa generasi muda masih merasa malu dan kampungan pada saat mereka menggunakan bahasa Bali, serta adanya anggapan bahwa bahasa Bali tidak dapat mengasilkan uang seperti bahasa-bahasa asing yang sering digunakan di daerah pariwisata. Pengaruh dari pergaulan selain memberikan dampak yang positif terhadap perkembangan kehidupan masyarakat Bali juga dirasa sebagai salah satu kendala dalam penggunaan dan pengembangan bahasa Bali. Hal ini disebabkan karena pengaruh pergaulan memberikan dampak yang sangat signifikan terhadap generasi muda pada zaman modern seperti sekarang. Adanya tayangan-tayangan sinetron di televisi memberikan pengaruh yang cukup besar terhadap kehidupan sosial generaasi muda di lingkungan masyarakat. munculnya gaya-gaya menirukan tayangan sinetron di televisi juga memberikan dampak terhadap penggunaan bahasa seseorang, seperti munculnya bahasa-bahasa baru yang mulai ditirukan oleh generasi muda. Kendala lainnya adalah adanya kelas sosial masyarakat yang menyebabkan penggunaan bahasa yang bervariasi dengan orang-orang tertentu. Dalam tingkatan kelas sosial dimasyarakat juga menggunakan sor singgih basa Bali dalam berkomunikasi dengan orang-orang yang berasal dari kelas sosial yang berbeda, seperti masyarakat dari golongan Tri Wangsa, para pejabat, pengusaha, dan lain sebagainya.

Melihat fenomena yang terjadi di masyarakat seperti itu, maka diupayakan beberapa hal oleh para panglingsir dan dibantu oleh seluruh komponen masyarakat agar bahasa Bali tetap bertahan di daerah pariwisata Candidasa. Upaya yang dilakukan masyarakat adalah dengan memperkenalkan bahasa Bali sejak dini. Pilihan bahasa pertama yang dikenalkan oleh orang tua kepada anaknya menjadi sangat penting, karena hal ini akan berpengaruh dan terbawa sampai dewasa oleh anak tersebut. Upaya selanjutnya adalah menggunakan bahasa Bali secara konsisten di lingkungan keluarga, dari upaya ini diharapkan anak-anak di lingkungan keluarga yang secara konsisten menggunakan bahasa Bali akan terpengaruh juga menggunakan bahasa Bali. pada saat bersosialisasi di luar lingkungan keluarga. Menanamkan rasa cinta terhadap budaya Bali dilakukan oleh masyarakat daerah Candidasa,hal ini dilakukan dengan cara mengadakan lomba-lomba yang berkaitan dengan budaya Bali, seperti lomba pidarta bahasa Bali, masatua Bali, lomba baleganjur, dan lain sebagainya. Diharapkan melalui event-event seperti ini generasi muda khususnya mulai mencintai dan bangga serta mau mempelajari budaya-budaya Bali tersebut. Sehingga budaya bali tetap ajeg dan lestari.

\section{Daftar Pustaka}

Chaer, Abdul. 2008. Morfologi Bahasa Indonesia (Pendekatan Proses). Jakarta : Rineka Cipta.

Geriya, I Wayan. 2008. Transformasi Kebudayaan Bali Memasuki Abad XXI. Surabaya : Paramita

Indrawan Jendra, Made Iwan. 2011. Sosiologi Bahasa Bali. Denpasar : Vidia

Jendra, I Wayan. 2007. Sosiolinguistik Teori dan Penerapannya. Surabaya : Paramita.

Kayam, Umar. 1989. Seni, Tradisi, Masyarakat. Jakarta : Sinar Harapan.

Parwati, Eny Sang Ayu Putu. 2011. Kebertahanan Bahasa Bali Komunitas Remaja Kuta, Badung. Universitas Udayana

Parwati, Desi Ni Komang. 2012. Campur Kode Pemakaian Bahasa Bali Bagi Pengelola Pariwisata di Kawasan Objek Wisata Penelokan, Desa Batur Tengah, Kecamatan Kintamani, Kabupaten Bangli : Fakultas Dharma Acarya

Pitana, I Gde. 1994. Dinamika Masyarakat dan Kebudayaan Bali. Denpasar : Offset BP.

Salim. 2002. Perubahan Sosial Sketsa Teori dan Refleksi Metodologi Kasus Indonesia. -:- 
Sancaya, Windu IDG. 2004. "Bahasa Bali Jagadhita : Bahasa Budaya dan Ilmu Pengetahuan" dalam Kumpulan Makalah Bali Menuju Jagadhita : Aneka Perspektif. Denpasar : Pustaka Bali Post.

Selamat, I Nengah. 2007. Pilihan Bahasa Pramuwisata Pendakian Gunung Batur dalam Berkomunikasi antar Pramuwisata. Singaraja : Undiksha

Suarjana, Putra I Nyoman. 2008. Sor-Singgih Basa Bali Ke-Bali-an Manusia Bali dalam Dharma Papadikan, Piddarta Sambrama Wacana dan Dharma wacana. Denpasar : Tohpati Grafika Utama.

Sudarsana, I. K. (2016, June). Praksis Teori Sosial Kognitif dalam Mengembangkan Karakter Peduli Sosial Pada Mahasiswa Jurusan Pendidikan Bahasa Dan Sastra Agama. In Seminar Nasional (No. ISBN : 978-602-74659-3-0, pp. 82-87). Institut Hindu Dharma Negeri Denpasar.

Sudrastini, Ni Ketut. 2014. Pemertahanan Bahasa Bali pada Masyarakat PariwisataPenelokan di Desa BAatur Tengah Kecamatan Kintamanai Kabupaten Bangli. Denpasar : IHDN

Sukayasa, I Made. 2011. Pemertahanan Bahasa Bali Sebagai Bahasa Komunikasi Pada Sekeha Tetuna-Teruni Widya Yohana Bhakti Dusin Ngis Desa Jegi Kecamatan Penebel Kabupaten Tabanan : Fakultas Dharma Acarya

Triguna, Yudha. 2008. "Strategi Holistik Pembangunan Bali Berbasis Agama, Budayadan Sains dalam Dinamika Lokal, Nasional dan Global" dalam KumpulanMakalah Kongres Kebudayaan Bali. Denpasar : Panitia Pelaksana KongresKebudayaan Bali Tahun 2008.

Yoeti, Oka A. 1990. Pengantar Ilmu Pariwisata. Bandung : Angkasa 